\title{
Trichomes of mericarpian species of the genus Galium (Rubiaceae) in Asian Russia
}

\author{
Ekaterina A. Pinzhenina* \\ Central Siberian Botanical Garden, 630090 Novosibirsk, Russian Federation
}

\begin{abstract}
The surface structure of mericarp of 16 species from 9 sections of the genus Galium, growing in Asian Russia, has been studied by scanning electron microscopy. Clothing trichomes were found on the surface of the fruit. It was noted that the clothing trichomes are distributed over the mericarp or concentrated in separate parts of it. Based on the results obtained, two morphological types and six subtypes of clothing trichomes were identified, which have taxonomic significance.
\end{abstract}

\section{Introduction}

Trichomes (hairs) are outgrowths of plant epidermal cells of various shapes and structures. They perform protective (clothing trichomes) and excretory (glandular trichomes) functions [1]. The botanical literature describes the structure, origin, development of clothing and glandular trichomes in detail in many groups of plants, compiled morphological descriptions and developed classifications of various types of trichomes [2-4]. Researchers have shown the diagnostic role of trichome traits in the taxonomy of individual families [4, 5] and genus [6,7].

Signs of trichomes of vegetative and generative organs are widely used in the taxonomy of the genus Galium L. (Rubiaceae). Researchers were paid attention to the these structures and use it in taxonomy of the genus Galium [8-10], but trichomes were not studied in detail. L.E. Muravnik and O.V. Kostina [11, 12] have identified that stipules of the species $G$. aparine L. and G. album Mill. pubescent with glandular hairs, which differ in size and location. In addition, the authors proved that in the process of ontogenesis, glandular hairs perform various functions and the metabolic direction of cells changes from the synthesis of polysaccharide mucus to the formation of secondary metabolites. Z.M. Al-Dabagh and I.K. Nasrullah [13] have studied the pubescence of stems, leaves, and fruits in five species $G$. aparine, G. ceratopodum Boiss, G. setaceum Lam., G. spurium L., G. tricornutum Dandy. They showed that trichomes are represented by simple unbranched hairs of two types, acumenated and hooked. The mericarps of $G$. aparine have peculiar hooked trichomes that contain polysaccharides and are involved in the sxpansion of the species [14].

The diversity of clothing trichomes of the species of the genus Galium growing in Asian Russia has not yet been studied enough: there are no data on the morphology and classification of hairs. This necessitated to identify of the types of trichomes, to describe of

* Corresponding author: baldk21@ngs.ru 
their morphology, as well as to determine of the possibility of using the types of trichomes in the taxonomy of the genus Galium.

\section{Materials and Methods}

Material for the study was ripe dry fruits stored in the herbaria of the V.L. Komarov Botanical Institute RAS (LE), N.V. Tsytsin Main Botanical Garden RAS (MHA), Faculty of Biology of Lomonosov Moscow State University (MW), Central Siberian Botanical Garden SB RAS (NS, NSK), South Siberian Botanical Garden of Altai State University (ALTB), Tomsk State University (TK). Investigation of the surface of fruits was carried out under a scanning electron microscope (Carl Zeiss EVO MA 10) in the Central Siberian Botanical Garden, the Siberian Branch of the Russian Academy of Sciences. The fruits were attached to the microscope stage with an adhesive tape, then gold was sputtered by means of a Mini SC 7620 device, followed by scanning.

The morphological description of the trichomes types was carried out using the terminology developed by T.A. Ostroumova, M.G. Pimenov and U.A. Ukrainskaya [4].

\section{Results and discussion}

The whole variety of fruit trichomes (mericarp) in species of the genus Galium growing in Asian Russia belongs to the group of non-glandular simple (unicellular) hairs, among which two types were identified: single sessile and single ones with a multi-row base (Table 1).

Table 1. Morphological classification of mericarp trichomes in species of the genus Galium of Asian Russia

\begin{tabular}{|c|c|c|c|}
\hline Group & Type & Subtype & Species \\
\hline \multirow{6}{*}{$\begin{array}{l}\text { Non-glandular } \\
\text { hairs }\end{array}$} & \multirow{3}{*}{ Single sessile } & Straight & $\begin{array}{l}\text { G. amurense, G. ruthenicum, } \\
\text { G. densiflorum }\end{array}$ \\
\hline & & Hook-shaped & G. mugodsharicum, G. boreale \\
\hline & & Sickle-shaped & $\begin{array}{l}\text { G. coriaceum, G. amblyophyllum, } \\
\text { G. lacteum }\end{array}$ \\
\hline & \multirow{3}{*}{$\begin{array}{l}\text { Single ones with a } \\
\text { multi-row base }\end{array}$} & Rounded & G. songaricum \\
\hline & & Flattened & G. aparine, G. vaillanti \\
\hline & & Ribbon-shaped & $\begin{array}{l}\text { G. odoratum, G. paradoxum } \\
\text { G. kamtschaticum, G. triflorum, } \\
\text { G. pseudoasprellum }\end{array}$ \\
\hline
\end{tabular}

The first type is characterized by the presence of one polygonal cell at the base of the trichomes. The hairs of different lengths have a conical shape with a sharp tip; they are marked: straight, hook-shaped and sickle-shaped.

Trichomes of the second type characterise by a certain number of polygonal cells (6-10) presented at the base. The cells raise the hair above the surface of the fetus. All hairs with a multi-row base have a conical or cylindrical shape with a sharp hook-shaped apex, which are divided into three subtypes: rounded, flattened, and ribbon-shaped.

There are single sessile straight hairs of a conical elongated shape with a sharp straight apex and a wide base, slightly compressed laterally. Trichomes of this subtype are found in the species G. amurense Pobed. (section Platygalium W.D.J. Koch), G. densiflorum Ledeb., G. ruthenicum Willd. (section Galium). In the species G. amurense, the hairs are 380-580 $\mu \mathrm{m}$ long., directed upward or slightly at an angle, densely located throughout the fruit. 
Trichomes of the species G. densiflorum and G. ruthenicum are 78-190 $\mu \mathrm{m}$ long, directed straight up or at an angle, sometimes appressed, fill the entire mericarp (Fig. 1.).

Single sessile hook-shaped hairs are hairs of a conical shape with a sharp hook-shaped apex, with a wide base, rounded, slightly compressed laterally. They are observed fore the species G. boreale L. and G. mugodsharicum Pobed. from the Platygalium section. $G$. mugodsharicum hairs are 100-160 $\mu \mathrm{m}$ long., sticking up, concentrated in the dorsal part of the mericarp. G. boreale has trichomes, 207-400 $\mu \mathrm{m}$ long, evenly distributed over the fruit, sticking out, located at an angle to the surface (Fig. 1).
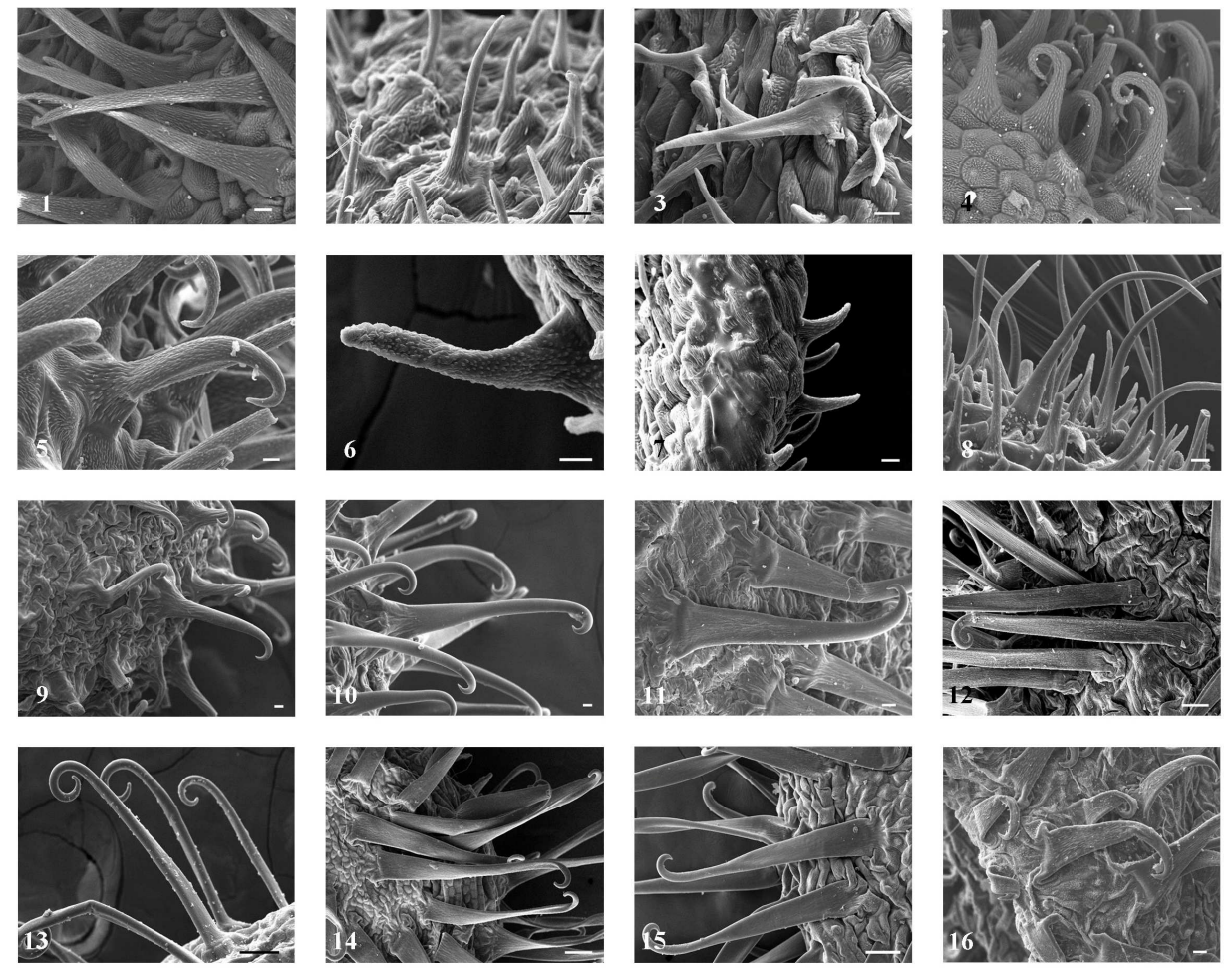

Fig. 1. Trichomes of mericarp species of the genus Galium: 1 - G. amurense; 2 - G. ruthenicum; 3 G. densiflorum; 4 - G. mugodsharicum; 5 - G. boreale; 6 - G. coriaceum; 7 - G. amblyophyllum; 8 G. lacteum; 9 - G. songaricum; 10 - G. aparine; 11 - G. vaillanti $; 12$ - G. odoratum; 13 - G. paradoxum; 14 - G. kamtschaticum; 15 - G. triflorum; 16 - G. pseudoasprellum. Scale bars: $20 \mu \mathrm{m}$ $(2,3,5,6,7,8,9,10) ; 30 \mu \mathrm{m}(11,16) ; 100 \mu \mathrm{m}(12,13,14,15) ; 200 \mu \mathrm{m}(1,4)$.

Single sessile crescent hairs of a conical shape with a sharp apex, slightly widened at the base, laterally compressed, are found in the species G. coriaceum Bunge (section Coriacea A. Jelen., Kuranova et Pjatunina), G. amblyophyllum Pobed. (section Platygalium) and G. lacteum (Maxim.) Pobed. (section Galium). Trichomes of the species G. coriaceum are rare, 30-50 $\mu \mathrm{m}$ long., appressed or slightly protruding, combined in the basal-dorsal part of the mericarp, absent at the apex. G. amblyophyllum has hairs, 11-15 $\mu \mathrm{m}$ long., appressed, very rare, dispersed, concentrated in the basal part of the fetus. Hairs of the species $G$. lacteum are described as 140-218 $\mu \mathrm{m}$ in long, directed upward at a right angle, densely distributed throughout the mericarp. There are trichomes of the species G. lacteum that are slightly depressed into the bases cell, the edges of the cell form a ridge (Fig. 1).

There are single, multi-row, rounded hairs of a cylindrical shape, rounded in cross section, slightly widened at the base, with a hook-shaped apex, evenly occupy the mericarp. This type of trichomes is found only in the species G. songaricum Schrenk. (section 
Depauperata Pobed.). The hairs of G. songaricum are 205-361 $\mu \mathrm{m}$ in long, sparse, protruding, directed upward, in the basal part there are 8 (10) large, dome-shaped cells that raise the hair above the fetal surface (Fig. 1).

Single, multi-row, flattened hairs of a conical shape, laterally compressed, oval in cross section, wide at the base, with a hook-shaped apex, are found in annual species G. aparine L., G. vaillantii DC. from the Aparine Lange section. Hairs are 250-480 $\mu \mathrm{m}$ long., spaced, localized throughout the fetus, sticking out, 10 (12) large, convex hair-lifting cells are at the base of the hair of the species G. aparine, or 8 (10) large, flat cells characterises of the species G. vaillantii (Fig. 1).

Single, multi-row, ribbon-shaped hairs are cone-shaped strongly compressed laterally, thin, widened at the base, hooked, characteristic of the species G. paradoxum Maxim., $G$. kamtschaticum Stell. ex Schult et Schult fil. (section Cymogalia Pobed.), G. odoratum (L.) Scop. (section Hylaeae (Griseb.) Ehrend.), G. triflorum Michx. (section Senifolia (Pobed.) A. Jelen., Kuranova et Pjatunina) and G. pseudoasprellum Makino (section Trachygalium K. Schum.). For the species of the Cymogalia section, dispersed, protruding hairs are characteristic, which are located completely along the mericarp, 440-730 $\mu \mathrm{m}$ long, at the base (6) of 8 large concave (G. kamtschaticum) or slightly convex (G. paradoxum) cells. On fruits of $G$. odoratum are observed protruding, densely located hairs throughout the fruit, 628-936 $\mu \mathrm{m}$ long., at the base with (6) 8 concave cells, which sometimes have the form of a cylinder. G. triflorum hairs are 260-350 $\mu \mathrm{m}$ long, upright, single occupy the entire surface of the mericarp, at the base of 6 (8) large, concave cells. Ttrichomes of the species G. pseudoasprellum are 295-370 $\mu \mathrm{m}$ long, upright, rarely appressed, concentrated in the dorsal part of the mericarp, at the base of 8 large, convex cells (Fig. 1).

Thus, in species of the genus Galium in Asiatic Russia, clothing trichomes on mericarps are represented by simple unicellular hairs. Dense and sparse pubescence is found on the fruits. It was revealed that trichomes are distributed evenly throughout the fruit $(G$. amurense, G. boreale, G. densiflorum, G. ruthenicum, G. lacteum, G. songaricum, $G$. aparine, G. vaillantii, G. paradoxum, G. kamtschaticum, G. odoratum, G. triflorum), sometimes concentrated in the dorsal (G. mugodsharicum), basal (G. amblyophyllum) or basal-dorsal $(G$. coriaceum) parts of the mericarp. The variety of trichomes on fruits is classified into two types - single sessile and single ones with a multi-row base. The hairs of the first type (single sessile) are straight, hook-shaped and sickle-shaped in the shape of the apex. The second type (single with a multi-row base) is characterized by the shape of the section of trichomes and is represented by rounded, flattened and ribbon-like hairs.

The species of the type section Galium are characterized by fruits with single sessile, straight or crescent hairs. For the species of the section Platygalium, fruits with single sessile straight, hooked, or sickle-shaped hairs were noted. In the Coriaceae section, fruits with single sessile sickle-shaped trichomes are observed. In the species of the sections Cymogalia, Senifolia, Hylaeae, and Trachygalium, single multi-row, ribbon-like hairs were found on fruits. Mericarps of the species of the Depauperata section are characterized by single multi-row, rounded hairs, and in the Aparine section, single multi-row flattened hairs are present on fruits.

The morphological types of the clothing trichomes we have noted have taxonomic significance and can be diagnostic at the species level.

The article used the material of the Bioresource collection of the Central Siberian Branch of the Siberian Branch of the Russian Academy of Sciences, UNU "Herbarium of Higher Vascular Plants, Lichens and Fungi (NS, NSK)", No. USU 440537.

This work was done within the framework of the state assignment of the Central Siberian Botanical Garden (the Siberian Branch of the Russian Academy of Sciences) on topic AAAA-A21-121011290024-5 "Biological Diversity of Cryptogamic Organisms and vessels of plants in North Asia and adjacent territories, their ecological and geographical 
characteristics and monitoring".

\section{References}

1. M. S. Gilyarov, Biological encyclopedic dictionary (Moscow, Soviet Encyclopedia, 1986)

2. Hanbuch der Pflanzenanatomie 4, 5 (Berlin; Stuttgart : Borntraeger,1962)

3. E. V. Baikova, Buletin of Mosow society of Naturalists, 106, 4 (2001)

4. T. A. Ostroumova, M. G. Pimenov, U. A. Ukrainskaya, Bot. J., 95, 9 (2010)

5. E. V. Boyko, Turczaninowia, 14, 2 (2011)

6. Yu. K. Vinogradova, A. S. Ryabchenko, S. R. Mayorov, Bot. J., 9, 1 (2013)

7. E. V. Baikova, T. D. Fershalova, E. A. Karpova, Plant life of Asian Russia, 2, 34 (2019)

8. A. P. de Candolle, Galium in Prodromus systematis naturalis regni vegetabilis, 4 (Parisiis, 1830)

9. E. G. Pobedimova, Galium in Flora URSS, 23 (Moscow; Leningrad, 1958)

10. F. Ehrendorfer, F. Krendl, Galium in Flora Europea, 4 (Cambridge, 1976)

11. L. E. Muravnik, O. V. Kostina, Bot. J., 95, 7 (2010)

12. L. E. Muravnik, O. V. Kostina, Bot. J., 96, 8 (2011)

13. Z. M. Al-Dabagh, I. K. Nasrullah, Plant Archives. 19, 1 (2019)

14. A. J. Bowling, H. B. Maxwell, K. C. Vaughn, Protoplasma 233 (2008) 